\title{
A STUDY OF THE RATE OF DISAPPEARANCE OF A DIGITALIS GLYCOSIDE (LANATOSIDE C.) FROM THE BLOOD OF MAN ${ }^{1}$
}

\author{
BY MEYER FRIEDMAN AND RENÉ BINE, JR. \\ (From the Harold Brunn Institute for Cardiovascular Research, Mount Zion Hospital, \\ San Francisco)
}

(Received for publication June 30, 1948)

\section{INTRODUCTION}

Exact quantitative determinations of either digitalis or its derivatives in the blood of patients or animals receiving these drugs have never been accomplished. The prime difficulty of course has been the inability to detect relatively minute amounts of digitalis or allied cardiotonic drugs in body fluids. Because of the absence of such quantitative data, very little is known about the actual fate in the body of either ingested or injected digitalis substances.

In previous studies $(1,2)$ we were able to detect by means of the embryonic duck heart preparation extremely minute amounts of a digitalis glycoside (Lanatoside C.) in both Tyrode's solution and in human blood. Moreover, the quantity of glycoside detectable (less than a microgram per cubic centimeter of blood) by this means suggested the possibility that the blood of patients receiving Lanatoside C. might be assayed for its glycoside content.

Accordingly, blood samples of ten patients who had received intravenously a therapeutic quantity of Lanatoside C. were assayed. It was found possible not only to detect in a quantitative fashion the presence of glycoside in such samples but also to measure the rate of the drug's disappearance from the blood stream.

\section{METHODS}

\section{A. Quantitative detection of Lanatoside $C$. in hu- man serum (in vitro)}

In a previous study (2) it was found that the embryonic duck heart exhibited a "digitalis effect" (the occurrence of $\mathrm{A}-\mathrm{V}$ block, missing beats or marked retardation of beating) when immersed in human serum containing $0.10 \mu \mathrm{g}$. or more of Lanatoside C. per cc. Furthermore, it was observed that the time necessary for

1 Aided by grants from the Life Insurance Medical Research Furd, the U. S. Public Health Service, and The Sandoz Chemical Works. the occurrence of the "digitalis effect" varied inversely with the amount of glycoside present in the serum samples. Finally, it was observed over a period of 20 months that no temporal variation occurred in the sensitivity of these embryonic hearts to a given concentration of Lanatoside C. These last findings offered the possibility of a method for the quantitative detection of glycoside.

Accordingly, different but known amounts of Lanatoside C. were added ( 0.10 to $1.0 \mu \mathrm{g}$. per cc. of serum) to samples of human serum and the various samples were refrigerated for 24 hours. Then five embryonic duck hearts were added to each sample and the individual times elapsing before occurrence of the "digitalis effect" were observed. This procedure was repeated until over 20 hearts had been exposed and observed in at least four different samples of serum containing the same concentration of glycoside. From these data, it was possible to construct a table whereby the quantity of Lanatoside C. in any serum sample could be determined by observation of the average time taken for five or more embryonic hearts to exhibit a typical "digitalis effect."

\section{B. Quantitative detection of Lanatoside C. in the patients' sera}

Serum samples were obtained from ten patients (seven of whom were suffering from either right or left congestive heart failure) who had not received any type of digitalis therapy within three months. To $1 \mathrm{cc}$. samples of each patient's serum, $0.10,0.15$ and $0.20 \mu \mathrm{g}$, respectively, of Lanatoside $\mathrm{C}$. were added. These samples together with one not containing glycoside were refrigerated for 24 hours and then each was tested on five embryonic hearts. The embryonic hearts were found to beat normally for at least 80 minutes in the control serum samples of each patient. Furthermore, the times elapsing for the occurrence of "digitalis effect" in hearts immersed in the various glycoside-serum samples corresponded in every case to the times previously observed for the same concentrations of Lanatoside C. as listed in the standard table. It was considered, therefore, that the serum of each of these patients was satisfactory for the quantitation by the duck heart method of possible Lanatoside C. content.

Approximately $1.6 \mathrm{mgm}$. of Lanatoside $\mathrm{C}$. were given by vein over a period of three minutes to each of the ten patients. Blood samples $(10 \mathrm{cc}$.) were obtained from the vein of the opposite arm immediately after the injection of the glycoside and again after $71 / 2,15,221 \frac{1}{2}$ and 30 
minutes. In several instances, samples also were taken at later intervals.

The blood samples were allowed to clot, the serum was removed and stored in the ice box for 24 hours. Six embryonic hearts then were added to two portions of each serum sample and the individual times elapsing before the occurrence of "digitalis effect" in each heart was noted exactly as described previously $(1,2)$. The time periods were averaged and compared to the standard table correlating the time elapsing before occurrence of "digitalis effect" in the embryonic hearts with the concentration of Lanatoside C. per cc. of serum. If a sample did not cause a "digitalis effect" within a period of 80 minutes, it was assumed, because of the previous study with known concentrations, that the sample contained less than $0.1 \mu \mathrm{g}$. of glycoside per cc. of serum. Therefore $0.1 \mu \mathrm{g}$. of the drug was added to $1 \mathrm{cc}$. of the same sample and tested again. If then the average time elapsing before occurrence of "digitalis effect" was the same as that occurring in samples known to contain $0.1 \mu \mathrm{g}$. per cc. it was assumed that the unknown sample contained less than $0.05 \mu \mathrm{g}$. per cc. If, on the other hand, such a sample caused the appearance of the "digitalis effect" in a time period equal to or shorter than that previously observed in samples containing $0.15 \mu \mathrm{g}$. per cc. it was concluded that the unknown sample contained at least $0.05 \mu \mathrm{g}$. per cc. In this manner, $0.05 \mu \mathrm{g}$. of Lanatoside C. per cc. of serum could be detected.

\section{RESULTS}

\section{A. The quantitative detection of Lanatoside $C$. in human serum (in vitro)}

As Table I demonstrates, serum samples containing concentrations of Lanatoside $\mathrm{C}$. differing for the most part by only $0.1 \mu \mathrm{g}$. per cc. could be

TABLE I

Relationship between concentration of Lanatoside $C$. and time of occurrence of "digitalis effect"

\begin{tabular}{|c|c|c|c|}
\hline \multirow{2}{*}{$\begin{array}{l}\text { Concent. of } \\
\text { glycoside }\end{array}$} & \multirow{2}{*}{$\begin{array}{c}\text { Number of } \\
\text { hearts }\end{array}$} & \multicolumn{2}{|c|}{$\begin{array}{l}\text { Time of occurrence, } \\
\text { "digitalis effect" }\end{array}$} \\
\hline & & Average & $\begin{array}{c}\text { Standard } \\
\text { error of } \\
\text { mean }\end{array}$ \\
\hline $\begin{array}{c}\mu g . / c c . \\
0.05 \\
0.10 \\
0.15 \\
0.20 \\
0.30 \\
0.40 \\
0.50 \\
0.60 \\
0.70 \\
0.80 \\
0.90 \\
1.00\end{array}$ & $\begin{array}{l}20 \\
26 \\
29 \\
33 \\
22 \\
21 \\
26 \\
20 \\
20 \\
22 \\
20 \\
20\end{array}$ & $\begin{array}{c}\text { min. } \\
\text { No effect } \\
62 \\
56 \\
43 \\
32 \\
26 \\
22 \\
17 \\
15 \\
13 \\
11 \\
11\end{array}$ & $\begin{array}{l}\min . \\
1.2 \\
1.3 \\
1.2 \\
2.0 \\
1.4 \\
1.8 \\
1.4 \\
0.5 \\
0.9 \\
0.9 \\
0.8\end{array}$ \\
\hline
\end{tabular}

quantitatively differentiated from each other by observation of the time of occurrence of "digitalis effect." The standard error of the mean of the values observed at any concentration was small enough to allow such quantitation except when concentrations of $0.8 \mu \mathrm{g}$. or more of glycoside per cc. of serum were present. These latter concentrations, however, were never reached in the blood of patients receiving therapeutic amounts of Lanatoside $\mathrm{C}$.

\section{B. The quantitative detection of Lanatoside $C$. in patients' sera after its intravenous injection}

As Table II indicates, the serum of each of the patients contained a detectable amount of Lanatoside C. immediately after the intravenous administration of $1.6 \mathrm{mgm}$. The average concentration of the glycoside was $0.25 \mu \mathrm{g}$. per cc. of serum (Range: 0.20 to 0.40 ). No significant difference was found in the serum concentration of the drug in patients with or without congestive failure.

The initial concentration of the glycoside, however, was not maintained for when nine serum samples obtained 7.5 minutes after administration of the drug were assayed, it was found that the average concentration of Lanatoside $C$. had fallen to $0.10 \mu \mathrm{g}$. per cc. of serum (Range : 0.05 to 0.15 ). At the end of 15 minutes, no glycoside could be detected in the sera of two of the ten patients. The sera of the remaining patients contained only 0.05 to $0.15 \mu \mathrm{g}$. per cc. At the end of 22.5 minutes, only two of eight patients tested still contained a detectable amount of Lanatoside $\mathrm{C}$. in their blood ( 0.05 to $0.10 \mu \mathrm{g}$. per cc.). At the end of 30 minutes, no Lanatoside C. (i.e., less than $0.05 \mu \mathrm{g}$. per cc.) could be found in the sera of nine of the ten patients. At the end of an hour, no glycoside was detected in the sera of the four patients tested. Finally the sera of two patients who exhibited signs of digitalis intoxication at the time the 24-hour sample was taken, 24 hours after injection did not contain a detectable amount of Lanatoside $\mathrm{C}$.

\section{DISCUSSION}

The quantitative detection of Lanatoside $\mathrm{C}$. in the blood of a patient or animal treated with this drug allows the future possibility of studying the fate of other digitalis glycosides in the human or 
TABLE II

The disappearance of Lanatoside $C$. from the serum of patients after its intravenous administration Concentration of Lanatoside $\mathrm{C}$. in serum after its injection

\begin{tabular}{|c|c|c|c|c|c|c|c|c|c|c|c|c|c|c|c|}
\hline $\begin{array}{c}\text { Subject } \\
\text { J. G. }\end{array}$ & \begin{tabular}{|c|}
$\begin{array}{c}\text { Cong. } \\
\text { heart } \\
\text { failure? }\end{array}$ \\
Yes
\end{tabular} & \multicolumn{2}{|c|}{ Immediately } & \multicolumn{2}{|c|}{ 7.5 Min. } & \multicolumn{2}{|c|}{15 Min. } & \multicolumn{2}{|c|}{ 22.5 Min. } & \multicolumn{2}{|c|}{$30 \mathrm{Min}$. } & \multicolumn{2}{|c|}{$60 \mathrm{Min}}$. & \multicolumn{2}{|c|}{24 Hours } \\
\hline $\begin{array}{l}\text { J. G. } \\
\text { R. S. } \\
\text { R. R. } \\
\text { J. M. } \\
\text { E. I. } \\
\text { J. J. } \\
\text { R. Z. } \\
\text { U. K. } \\
\text { C. C. } \\
\text { J. S. }\end{array}$ & $\begin{array}{l} \\
\text { Yes } \\
\text { Yes } \\
\text { Yes } \\
\text { Yes } \\
\text { Yes } \\
\text { Yes } \\
\text { Yes } \\
\text { No } \\
\text { No } \\
\text { No }\end{array}$ & $\begin{array}{c}T D E^{*} \\
37 \\
32 \\
36 \\
37 \\
49 \\
45 \\
44 \\
43 \\
25 \\
34\end{array}$ & $\begin{array}{c}\text { Mg. } / \text { /cc. } \\
0.25 \\
0.30 \\
0.25 \\
0.25 \\
0.20 \\
0.20 \\
0.20 \\
0.20 \\
0.40 \\
0.30\end{array}$ & $\begin{array}{c}T D E \\
55 \dagger \\
57 \\
54 \\
58 \\
54 \\
62 \\
60 \\
62 \\
63\end{array}$ & $\begin{array}{c}\mu \mu_{0} / c c . \\
0.05 \\
0.15 \\
0.15 \\
0.15 \\
-\overline{15} \\
0.15 \\
0.10 \\
0.10 \\
0.10\end{array}$ & $\begin{array}{l}T D E \\
62 \dagger \\
58 \\
52 \dagger \\
50 \dagger \\
54 \dagger \\
52 \dagger \\
56 \dagger \\
66 \dagger \\
61 \\
54 \dagger\end{array}$ & $\begin{array}{c}\mu g . / c c . \\
\text { ND } \\
0.15 \\
0.05 \\
0.05 \\
0.05 \\
0.05 \\
0.05 \\
\text { ND } \\
0.10 \\
0.05\end{array}$ & $\begin{array}{c}T D E \\
61 \dagger \\
62 \\
55 \dagger \\
61 \dagger \\
65 \dagger \\
63 \dagger \\
67 \dagger \\
\frac{60 \dagger}{60}\end{array}$ & $\begin{array}{c}\mu g_{.} / c c . \\
\text { ND } \\
0.10 \\
0.05 \\
\text { ND } \\
-\overline{N D} \\
\text { ND } \\
\text { ND } \\
\overline{N D}\end{array}$ & $\begin{array}{l}T D E \\
64 \dagger \\
62 \dagger \\
60 \dagger \\
66 \dagger \\
64 \dagger \\
63 \dagger \\
62 \dagger \\
65 \dagger \\
56 \dagger \\
67 \dagger\end{array}$ & $\begin{array}{l}\mu g . / c c . \\
\text { ND } \\
\text { ND } \\
\text { ND } \\
\text { ND } \\
\text { ND } \\
\text { ND } \\
\text { ND } \\
\text { ND } \\
0.05 \\
\text { ND }\end{array}$ & $\begin{array}{l}T D E \\
64 \dagger \\
64 \dagger \\
62 \dagger \\
= \\
= \\
= \\
\overline{-} \\
68 \dagger\end{array}$ & $\begin{array}{l}\mu g . / c c . \\
\text { ND } \\
\text { ND } \\
\text { ND } \\
= \\
= \\
= \\
\text { ND }\end{array}$ & $\begin{array}{l}T D E \\
60 \dagger \\
= \\
= \\
= \\
= \\
\overline{62 \dagger}\end{array}$ & $\begin{array}{c}{ }^{\mu g .} / c c . \\
\text { ND } \\
= \\
= \\
\bar{E} \\
\text { ND }\end{array}$ \\
\hline \multicolumn{2}{|c|}{ Average } & 38 & 0.25 & & 0.10 & & & & & & & & & & \\
\hline
\end{tabular}

*TDE equals average time of occurrence of "digitalis effect" in five embryonic hearts.

$\dagger 0.1 \mu \mathrm{g}$. of Lanatoside C. added to each cc. of serum sample.

$¥ N D$ indicates that no Lanatoside C. could be detected in serum sample.

animal body. Little is known at present about this matter.

The present study has resulted not only in a quantitative estimation of the actual amount of Lanatoside C. in the blood of a patient immediately after the intravenous administration of the drug but even more important, has allowed us to determine its rate of disappearance from the blood stream.

In a previous study (2) it was found that when this particular glycoside was added to whole blood, little or none was adsorbed or contained in the blood cells. Therefore, the rapid disappearance of Lanatoside C. from the serum of our patients (usually over 80 per cent within 22.5 minutes after administration) could not be explained by its entrance into or adsorption by blood cells. Nor could the rapid disappearance be due to inactivation of the Lanatoside $C$. by serum, which was found in the previous study to be unable to do so (2). Also, in view of the fact that the plasma proteins were not able to adsorb this particular glycoside (2), it seems most likely that the rapid disappearance of Lanatoside $C$. from the blood stream was due to its actual escape therefrom by the simple process of diffusion.

It is perhaps worthy of note that the rate of disappearance of the drug from the blood stream did not appear to be affected by the presence or absence of congestive heart failure. It is interesting too that two patients experienced symptoms of digitalis intoxication 24 hours after administration of Lanatoside $C$., at which time none of it could be detected in their blood.

\section{SUMMARY}

1. The quantitative detection of small amounts of Lanatoside C. in human serum was accomplished.

2. The rate of disappearance of this glycoside from the blood of ten human subjects after its intravenous administration was observed.

3. The probable reason for the rapid disappearance of Lanatoside C. from the blood stream of the experimental subjects was discussed.

\section{ACKNOWLEDGMENTS}

The authors wish to express their thanks to Sanford O. Byers, Catherine Shuey, Eleanor G. Bine, Maude Gardner, Nancy Bryant and Sidney Byers for their assistance in this study.

The authors also are indebted to the owners of the Reichardt Duck Farm (Colma, California) for their splendid cooperation in the execution of this study.

\section{BIBLIOGRAPHY}

1. Friedman, M., and R. Bine, Jr., Employment of the embryonic duck heart for the detection of minute amounts of a digitalis glycoside (Lanatoside C.). Proc. Soc. Exper. Biol. \& Med., 1947, 64, 162.

2. Bine, R., Jr., and Friedman, M., Observations concerning the effects of blood upon the action of a digitalis glycoside. Am. J. Med. Sc. To be published. 